\title{
Prehistoric Ceramic Sherds from 41MM341 on the Little River, Milam County, Texas
}

Timothy K. Perttula

Heritage Research Center, Stephen F. Austin State University

Follow this and additional works at: https://scholarworks.sfasu.edu/ita

Part of the American Material Culture Commons, Archaeological Anthropology Commons, Environmental Studies Commons, Other American Studies Commons, Other Arts and Humanities Commons, Other History of Art, Architecture, and Archaeology Commons, and the United States History Commons

Tell us how this article helped you.

This Article is brought to you for free and open access by the Center for Regional Heritage Research at SFA ScholarWorks. It has been accepted for inclusion in Index of Texas Archaeology: Open Access Gray Literature from the Lone Star State by an authorized editor of SFA ScholarWorks. For more information, please contact cdsscholarworks@sfasu.edu. 
Prehistoric Ceramic Sherds from 41MM341 on the Little River, Milam County, Texas

\section{Creative Commons License}

\section{(c) (1) (8)}

This work is licensed under a Creative Commons Attribution-NonCommercial 4.0 International License 


\title{
Prehistoric Ceramic Sherds from 41MM341 on the Little River, Milam County, Texas
}

\author{
Timothy K. Perttula
}

\section{INTRODUCTION}

Site $41 \mathrm{MM} 341$ is a stratified Late Prehistoric site along the Little River in Milam County, Texas, not far from the confluence of the Little River and the Brazos River (Mahoney and Tomka 2001). Calibrated two-sigma radiocarbon dates from Zone 2 (ca. $70-90 \mathrm{~cm}$ bs) range from AD 660-1190, and one two-sigma calibrated date of AD 13201480 has been obtained from Zone 1 ( 0 to ca. $70 \mathrm{~cm} \mathrm{bs}$ ). A few ceramic sherds were found in Zone 1 deposits. Based on the Zone 1 calibrated radiocarbon date, Mahoney and Tomka (2001:51) concluded that the latest occupation of 41MM34I took place during the Toyah phase, and they also concluded that "based on construction method and temper, these [ceramic] specimens are likely to date to the later part of the Late Prehistoric Period (i.e., Toyah Phase)."

\section{ANALYSIS OF THE CERAMIC SHERDS}

Thirteen prehistoric ceramic sherds have been recovered from $41 \mathrm{MM} 341$ on the Little River in Milam County, Texas, during recent archeological investigations by the Center for Archaeological Research, University of Texas at San Antonio (Mahoney and Tomka 2001:52). At the time of the analysis, the prehistoric component at the site was thought to date to about 1050 B.P. or younger, but subsequent radiocarbon dating indicates that the Late Prehistoric component with ceramics likely dates to the $14^{\text {th }}$ and $15^{\text {th }}$ centuries. The sherds are from Zone $1,20-30 \mathrm{~cm}$ bs, in Block 1 , Unit A ( $\left.\mathrm{n}=2\right)$, Unit B $(\mathrm{n}=9)$, and BHT $24(\mathrm{n}=2)$.

The sherds are from two different vessels. The first vessel ( $\mathrm{n}=11$ sherds, including five sherdlets from Unit B) is represented by all the sherds from Unit A and BHT 24, and seven of the sherds in Unit B; the sherdlets are less than $1 \mathrm{~cm}$ in length and width. This vessel has finely crushed and burned bone temper inclusions, and it has been fired in a reducing or low oxygen environment (cf. Teltser 1993:Figure 2B). The sherd cores are black. The sherds are from the body of a thick-walled vessel, probably a jar; the body wall thickness ranges from $6.9-9.4 \mathrm{~mm}$, with a mean of $8.8 \pm 0.6 \mathrm{~mm}$. Two of the body sherds have a smoothed exterior surface, and one (from BHT 24) has remnants of an organic residue from use of the vessel for cooking foodstuffs.

The second vessel includes two sherds from Unit B. The sherds are from a carinated bowl with bone and grog temper, and the clay paste is sandy. The carinated bowl had been fired in a reducing environment, but cooled in a high oxygen environment (cf. Teltser 1993:Figure 2F). Body wall thickness ranges from 7.9-8.4 mm, with a mean of $8.15 \pm 0.25 \mathrm{~mm}$. One of the carinated bowl sherds has a single broad horizontal incised 
line above the carination, and it is likely the decorative element consists of multiple horizontal lines on the rim of the vessel.

\section{DISCUSSION}

Although the ceramic sherds from 41MM341 are tempered with bone, the limited amount of bone in the paste (less than $10 \%$ of the paste matrix), the thick body walls, which are almost twice as thick as bone-tempered Leon Plain from Central Texas Toyah phase sites (see below), and the absence of well-burnished exterior and/or interior surfaces indicate that the bone-tempered wares from the site are not from Leon Plain vessels (for a review of the characteristics of Toyah phase ceramics and Leon Plain, see Suhm and Jelks [1962] and Ricklis [1995:196-197]). Whether it is a locally-made vessel is unknown at the present time, although this seems a reasonable conclusion.

As mentioned above, the few bone-tempered sherds from 41MM341 are not burnished, and do not have abundant crushed bone temper, both attributes of which are characteristic of Toyah phase ceramics (see Johnson 1994:187-210). They also have thick vessel body walls, ranging from $6.9-9.4 \mathrm{~mm}$. Table 1 provides information on rim, body, and base wall thickness of bone-tempered ceramics from a range of Toyah phase sites in the Classic Toyah Culture area defined by Johnson (1994:Figure 105). Site 41MM341 falls outside the boundary of the Classic Toyah Culture area as well as the tentative boundary of a "greater Toyah cultural sphere" (Johnson 1994:243).

Table 1. Thickness of Bone-Tempered Sherds in Selected Toyah Phase Assemblages.

\begin{tabular}{|c|c|c|c|c|}
\hline Site & Vessel Group & $\begin{array}{l}\mathrm{Rim} / \text { Body } \\
(\mathrm{mm})\end{array}$ & $\begin{array}{l}\text { Base } \\
(\mathrm{mm})\end{array}$ & Reference \\
\hline $41 \mathrm{HY} 202-\mathrm{A}$ & & $5-8$ & $9-9.5$ & Ricklis 1994 \\
\hline 41HY209-T & & $3-6$ & - & \\
\hline 41HY209-M & & $6-8$ & - & \\
\hline 41JW8 & & 6.1 & - & Black 1986 \\
\hline \multirow[t]{2}{*}{ 41KM16 } & $1-9$ & $3.4-6.7$ & - & Johnson 1994 \\
\hline & 11 & $8-8.7$ & - & \\
\hline \multirow[t]{2}{*}{ 41LK201 } & $\begin{array}{l}9,11,12,14 \\
19\end{array}$ & $3.5-7$ & - & Highley 1986 \\
\hline & $10 \mathrm{~A}$ & $7-9$ & $6-10$ & \\
\hline \multirow{2}{*}{$41 \mathrm{TG} 346$} & $1-4,7$ & $3-6.9$ & & Quigg and Peck 1995 \\
\hline & 6 & - & $8-9.9$ & \\
\hline $41 V \vee 344$ & & $2.6-7.3$ & - & Mehalchick et al. 1999 \\
\hline 41 WN88 & & $4.1-7.9$ & - & Nickels 2000 \\
\hline
\end{tabular}

With the exception of one sizeable bone-tempered vessel from the Buckhollow site (41KM16) (Johnson 1994:203), and a bottle (Group 10A) from 41LK201, the vessel 
body thickness of the Toyah phase ceramics listed in Table 1 range as a group only from 2.6-8 $\mathrm{mm}$. This ceramic date provides further confirmation that the bone-tempered ceramics from $41 \mathrm{MM} 341$ are not affiliated with the Toyah phase, and as such cast doubt on the attribution of the $14^{\text {th }}$ and $15^{\text {th }}$ century occupation there as belonging to the Toyah phase. I suggest that the roots of the Late Prehistoric occupation at 41MM341 rest more locally in the Brazos and Navasota River drainage basins of Texas.

The occurrence of grog temper in the incised carinated bowl from 41MM341 strongly suggests that this vessel was made in the Caddoan area of northeastern Texas. Grog temper is widely used in Caddoan vessels of all time periods, and the carinated bowl form also appears to be a Caddoan innovation in Texas. To ascertain the manufacturing locale of the two different vessels, I recommend that a sherd from each vessel be analyzed by instrumental neutron activation analysis (INAA) and petrographic analysis. The current INAA and petrographic databases for Caddoan and Central Texas ceramics are sufficiently robust (see Perttula 1999) to be able to determine the likely compositional origin of the two vessels.

Similar bone and/or grog-tempered sherds have been reported from Post Oak Savanna sites in east central Texas, particularly in the Navasota River basin, although prehistoric ceramics are not abundant in contexts dating from 1250-250 B.P. (Fields 1995:314-318, 323-324). These ceramics, like those from 41MM341, do not have Toyah phase affiliations.

At sites in Grimes County, for example, there are plain and decorated grog and bone-tempered sherds, and plain sherds with bone temper and/or sandy pastes; the decorated sherds have stylistic affiliations with Caddoan wares as well as San Jacinto wares made on the upper Texas coast (Rogers 1995). Turpin and Carpenter (1994:17) recovered thick $(9.0 \mathrm{~mm})$ and undecorated grog-tempered sandy paste sherds at 41RT285 on Walnut Creek, near its confluence with the Brazos River, but in a context postdating A.D. 1250. At site 41RT510 in the Navasota River basin (Perttula n.d.), grog, grog-sandy paste, and bone-tempered sherds from plain jars and bowls are relatively abundant $(\mathrm{n}=36)$, and the vessels are also relatively thick $(6.6-10.5 \mathrm{~mm})$. Rims are direct with rounded or flattened lips, and the sherds are from vessels primarily reduced during firing $(83 \%)$. The few decorated sherds in the 4IRT510 collection--horizontal and diagonal incised lines and fingernail punctated elements--suggest that the ceramics from this site date from ca. A.D. 900-1200, but are apparently slightly older than the ceramics from $41 \mathrm{MM} 341$. 


\section{REFERENCES CITED}

Black, S. L.

1986 The Clemente and Herminia Hinojosa Site, 41JW8: A Toyah Horizon Campsite in Southern Texas. Special Report No. 18. Center for Archaeological Research, The University of Texas at San Antonio.

Fields, R. C.

1995 The Archeology of the Post Oak Savannah of East Central Texas. Bulletin of the Texas Archeological Society 66:301-330.

Highley, C. L.

1986 Archaeological Investigations at 41LK201, Choke Canyon Reservoir, Southern Texas. Choke Canyon Series, Volume 11. Center for Archaeological Research, The University of Texas at San Antonio.

Johnson, L., Jr.

1994 The Life and Times of Toyah-Culture Folk: The Buckhollow Encampment, Site 41KM16, Kimble County, Texas. Office of the State Archeologist Report 38. Texas Historical Commission and Texas Department of Transportation, Austin.

Mahoney, R. B. and S. A. Tomka

2001 National Register Eligibility Testing of 41MM340 and 41MM341, along Little River, Milam County, Texas. Archeological Studies Program, Report No. 30, Environmental Affairs Division, Texas Department of Transportation, Austin, and Archaeological Survey Report No. 303, Center for Archaeological Research, The University of Texas at San Antonio.

Mehalchick, G., T. Myers, K. W. Kibler, and D. K. Boyd

1999 "Val Verde on the Sunny Rio Grande": Geoarcheological and Historical Investigations at San Felipe Springs, Val Verde County, Texas. Reports of Investigations No. 122. Prewitt and Associates, Inc., Austin.

Nickels, D. L.

2000 The Biesenbach Site (41WN88): A Case Study in Diet Breadth. Masters thesis, College of Liberal and Fine Arts, Division of Behavioral and Cultural Sciences, The University of Texas at San Antonio.

Perttula, T. K.

1999 Ceramic Evidence for Prehistoric Caddoan Trade and Exchange. Mini-NSF Grant Proposal on file, Research Reactor Center, University of Missouri, Columbia.

n.d. The Ceramic and Lithic Assemblage from a Late Prehistoric Site (41RT510) in the Post Oak Savanna, Robertson County, Texas. MS in preparation. 
Quigg, J. M. and J. Peck

1995 The Rush Site (41TG346): A Stratified Late Prehistoric Locale in Tom Green County, Texas. Technical Report No. 816C. Mariah Associates, Inc., Austin.

Ricklis, R. A.

1994 Toyah Components: Evidence for Occupation in the Project Area during the Latter Part of the Late Prehistoric Period. In Archaic and Late Prehistoric Human Ecology in the Middle Onion Creek Valley, Hays County, Texas, by R. A. Ricklis and M. B. Collins, pp. 207-316. 2 Vols. Studies in Archeology 19. Texas Archeological Research Laboratory, The University of Texas at Austin.

1995 The Ceramics of the Toyah Horizon and the Rockport Phase as Indicators of Some Basic Sociocultural Patterns. Bulletin of the Texas Archeological Society 66:195-203.

Rogers, $\mathbf{R}$.

1995 Archeological Excavations at Prehistoric Sites 4IGM166, 41GM281, and 4 IGM282 at the Gibbons Creek Lignite Mine, Grimes County, Texas. Document No. 940611 . Espey, Huston \& Associates, Inc., Austin.

Suhm, D. A. and E. B. Jelks (editors)

1962 Handbook of Texas Archeology: Type Descriptions. Special Publication No. 1, Texas Archeological Society, and Bulletin No. 4, Texas Memorial Museum, Austin.

Teltser, P. A.

1993 An Analytic Strategy for Studying Assemblage-Scale Ceramic Variation: A Case Study from Southeast Missouri. American Antiquity 58(3):530-543.

Turpin, J. and S. M. Carpenter

1994 Continuing Cultural Resource Management at Calvert Mine: 1993 Prehistoric Site Testing, Robertson County. Technical Series No. 42. Texas Archeological Research Laboratory, The University of Texas at Austin. 